\title{
Pengaruh konsentrasi zpt giberalin dan lama penyinaran terhadap pertumbuhan dan hasil tanaman krisan (Chrysanthemum morifolium)
}

\section{(The effect of gibberallin concentration and irradiation duration on the growth and yield of chrysanthemum cut flowers (Chrysanthemum morifolium))}

\author{
D. Rifalasna, Sumarsono, dan B. A. Kristanto \\ Agroecotechnology, Faculty of Animal and Agricultural Sciences, Diponegoro University \\ Tembalang Campus, Semarang 50275 - Indonesia \\ CorrespondingE-mail: dian.rifalasna@gmail.com
}

\begin{abstract}
This study aimed to examine the effect of giberalin concentration and duration of irradiation on the growth and yield of chrysanthemum (Chrysanthemum morifolium) cut flowers. The study took place in February - June 2018. The study was conducted in Mendongan Village, Sumowono District, Semarang Regency, Central Java. The design used in the study was a Completely Randomized Factorial 4x4 Design. The first factor was gibberallin treatment consisted of G1: GA 0 ppm, G2: GA 10 ppm, G3: GA 20 ppm, G4: GA 30 ppm. The second factor was the irradiation time consisted of R1: 1 hour irradiation time, R2: 2 hours irradiation time, R3: 3 hours irradiation time, and R4: 4 hours irradiation time. Parameters observed were plant height, stem diameter, number of leaves, leaf area, number of flowers, flower diameter, flowering age and flower harvesting age. The results showed that the treatment of giberalin concentration significantly affected the parameters of the amount of interest. While the irradiation treatment time significantly affected the parameters of plant height, number of leaves, flower diameter, stem diameter, age of flowering, and leaf area.
\end{abstract}

Keywords: Giberalin, Chrysanthemum, Irradiation Period

\begin{abstract}
ABSTRAK
Penelitian ini bertujuan untuk mengkaji pengaruh konsentrasi ZPT giberalin dan lama penyinaran terhadap pertumbuhan dan hasil bunga potong tanaman krisan (Chrysanthemum morifolium). Penelitian berlangsung pada bulan Februari - Juni 2018. Penelitian dilakukan di Desa Mendongan, Kecamatan Sumowono, Kabupaten Semarang, Jawa Tengah. Rancangan yang digunakan dalam penelitian adalah Percobaan Faktorial 4x4 Rancangan Acak Lengkap (RAL). Faktor pertama yaitu perlakuan giberalin sebanyak 4 taraf yaitu G1 : GA 0 ppm, G2 : GA 10 ppm, G3 : GA 20 ppm, G4 : GA 30 ppm. Faktor kedua adalah lama penyinaran dengan 4 taraf yaitu R1 : lama penyinaran 1 jam, R2 : lama penyinaran 2 jam, R3 : lama penyinaran 3 jam, dan R4 : lama penyinaran 4 jam. Parameter yang diamati adalah tinggi tanaman, diameter batang, jumlah daun, luas daun, jumlah bunga, diameter bunga, umur berbunga dan umur panen bunga. Hasil penelitian menunjukkan bahwa konsentrasi giberalin berpengaruh nyata terhadap peningkatan jumlah bunga yang bertambah banyak. Sedangkan lama penyinaran berpengaruh nyata terhadap peningkatan tinggi tanaman, jumlah daun, diameter bunga, diameter batang, umur berbunga, dan luas daun.
\end{abstract}

Kata Kunci : Giberalin, Krisan, Lama Penyinaran

\section{PENDAHULUAN}

Krisan termasuk salah satu jenis bunga potong penting di dunia, yaitu diantara 10 jenis bunga komersial krisan menempati urutan kedua setelah mawar. Selain sebagai tanaman hias dan bunga potong, krisan dimanfaatkan sebagai tanaman obat tradisional untuk obat batuk, nyeri 
perut, sakit kepala akibat peradangan sinus (sinusitis) dan sesak napas (Mulyatna, 2011). Krisan merupakan bunga potong dan tanaman pot yang paling digemari baik di pasar dalam negerimaupun perdagangan internasional. Beberapa tahun terakhir, krisan termasuk salah satu komoditas ekspor bunga potong Indonesia. Di Indonesia, permintaan krisan dari tahun ke tahun semakin meningkat. Permintaan bunga krisan pada tahun 2009 sebanyak 99.158 .942 potong dan meningkat pada tahun 2009 sebanyak 107.847.072 potong. Sedangkan produksi krisan pada tahun 2009 sebesar 107.847.072 potong atau produktivitas krisan sebesar 11,07 potong $/ \mathrm{m}^{2}$ pada luas panen sebesar $9.742 .677 \mathrm{~m}^{2}$, kemudian pada tahun 2010 meningkat menjadi $10.024 .605 \mathrm{~m}^{2}$ dan produktivitas sebesar 17,58 potong $/ \mathrm{m}^{2}$, untuk pemasaran dalam negeri krisan dijualseharga $\mathrm{Rp}$ 8.000, sampai dengan Rp10.000, per ikat yang terdiri dari 10 tangkai. Bahkan setelah berbentuk rangkaian bunga harganya berkisar Rp 100.000, sampai dengan Rp 400.000,(BPS, 2010).

Salah satu usaha yang dapat dilakukan untuk memacu pertumbuhan adalah dengan pemberian zat pengatur tumbuh berupa giberalin, giberalin tidak hanya merangsang perpanjangan batang tetapi juga pertumbuhan tanaman secara keseluruhan termasuk daun dan akar (Lakitan, 2011). Peningkatan tanaman krisan dilakukan melalui teknik penanaman diikuti dengan pengaplikasian zat pengatur tumbuh, salah satunya adalah pemberian GA3 (Harjadi, 2013).

Aplikasi GA3 dengan konsentrasi 150 ppm pada tanaman krisan dapat mempercepat pembelahan sel meristem sehingga meningkatkan tinggi tanaman yaitu sebesar $81-87 \mathrm{~cm}$. Aplikasi GA3 dengan konsentrasi $150 \mathrm{ppm}$ nyata dapat mempercepat pembungaan yaitu rata-rata tanaman 44-50 hari dan umur panen bunga krisan yaitu rata- rata tanaman 62-75 hari setelah pemberian GA3 sehingga dapat menghemat biaya produksi. (Nasihin, 2008). Pada perlakuan konsentrasi GA3 tampak adanya perbedaan yang sangat nyata terhadap saat munculnya bunga dan diameter bunga. Pemberian konsentrasi $25 \mathrm{ppm}$ menunjukkan hasil yang memuaskan yaitu tanaman dapat berbunga lebih awal yaitu ratarata umur tanaman 64,53 hari setelah tanam dan diameter bunga $12,50 \mathrm{~cm}$, sedangkan pada konsentrasi 0 ppm menunjukkan hasil yang kurang memuaskan, tanaman baru berbunga setelah berumur ratarata 89,63 hari setelah tanam yang artinya saat munculnya bunga lebih lambat, sedangkan diameter bunga hanya $6,75 \mathrm{~cm}$. Secara umum perlakuan terbaik adalah umur bibit 2 minggu dan konsentrasi GA3 25 ppm dimana saat munculnya bunga tercepat dan diameter bunga terbesar (Widyastuti, 2014).

Cahaya tambahan diberikan dengan cara terus menerus dengan lampu menyala selama 4-6 jam untuk memberi pengaruh panjang hari sampai 4-6 minggu setelah tanam (Edy, 2012). Tanaman krisan tanpa penambahan cahaya memiliki umur panen yang lebih cepat (Marwoto, 2014).

Penambahan cahaya buatan paling baik sekitar 3-4 jam pada pukul 22.00 sampai dengan 02.00 dini hari. Tanaman krisan dengan penambahan cahaya 3-4 jam menghasilkan tinggi tanaman paling tinggi yaitu $68-75 \mathrm{~cm}$ dan diameter bunga paling tinggi yaitu $8,2-11,5 \mathrm{~cm}$. Penambahan cahaya dilakukan selama 45 hari memiliki pengaruh yang cukup baik terhadap pertumbuhan tanaman krisan, hal ini terlihat pada jumlah daun tanaman krisan saat 7 MSPT yang banyak (Sutisna, 2010). Penambahan cahaya buatan meningkatkan panjang tangkai bunga yang sama panjang pada perlakuan 4 dan 5 jam yaitu masing-masing sebesar $54,82 \%$ dan $55,46 \%$, dan lebih tinggi dibandingkan penambahan cahaya buatan 2 dan 3 jam yang hanya meningkatkan panjang tangkai masing-masing sebesar $43,81 \%$ dan 51,02\% (Lilik, 2014).

Penelitian ini bertujuan untuk menguji pengaruh tingkat lama penyinaran dan pengaruh tingkat konsentrasi giberalin terhadap pertumbuhan dan hasil bunga tanaman krisan, menguji pengaruh interaksi antara lama penyinaran dan tingkat konsentrasi giberalin pada pertumbuhan dan hasil bunga potong tanaman krisan.

\section{MATERI DAN METODE}

Penelitian pengaruh konsentrasi giberalin dan lama penyinaran terhadap pertumbuhan dan hasil bunga potong tanaman krisan (Chrysanthemum morifolium) telah dilaksanakan pada bulan Februari-Juni 2018 di Desa Mendongan, Kecamatan Sumowono, Kabupaten Semarang, Jawa Tengah. 


\section{Materi}

Penelitian menggunakan alat dan bahan meliputi 4 bedengan luas bedengan $250 \times 350 \mathrm{~cm}$, hormon serbuk Giberalin, 4 lampu pijar LED 35 watt, sebanyak 720 bibit krisan putih, greenhouse atap berbahan plastik UV, bedengan gunting/cutter, penggaris, jangka sorong, leafmeter, alat dan buku tulis, kertas label, tanah homogen, pupuk kandang, pupuk NPK mutiara, air, insektisida, fungisida, , kamera digital.

\section{Metode}

Metode penelitian ini dimulai dari
Mendongan, Kecamatan Sumowono, Kabupaten Semarang, Jawa Tengah. Prosedur penelitian dimulai dari pembibitan tanaman krisan yang dilakukan selama 15 hari dengan cara pembibitan di atas arang sekam pada greenhouse. Kemudian menyiapkan bibit krisan Fiji putih (putih) dengan menanam 760 bibit krisan pada ke lahan dengan jarak tanam $11 \mathrm{~cm}$, tinggi lampu $2 \mathrm{~m}$ dari permukaan tanah. Penambahan cahaya diberikan selama 40 hari pada fase vegetatif dengan diberikan sekat disetiap perlakuan. Pencahayaan dilakukan selama fase vegetatif tanaman krisan yaitu pada umur 2-6 minggu dengan menggunakan lampu pijar LED sebesar 35

Tabel 1. Tinggi Tanaman Hasil Bunga Krisan pada Konsentrasi ZPT Giberalin dan Lama Penyinaran

\begin{tabular}{|c|c|c|c|c|c|}
\hline \multirow{2}{*}{$\begin{array}{c}\text { Konsentrasi } \\
\text { Giberalin (ppm) }\end{array}$} & \multicolumn{4}{|c|}{ Lama Penyinaran (Jam) } & \multirow[t]{2}{*}{ Rata-rata } \\
\hline & 1 jam $(\mathrm{R} 1)$ & 2 jam (R2) & $3 \mathrm{jam}(\mathrm{R} 3)$ & 4 jam (R4) & \\
\hline & & \multicolumn{3}{|c|}{ - } & \\
\hline 0 ppm (G1) & 62,5 & 67,9 & 64,5 & 93,5 & 72,1 \\
\hline 10 ppm (G2) & 62,2 & 68 & 64,9 & 96,7 & 72,9 \\
\hline 20 ppm (G3) & 64,5 & 70,4 & 66,8 & 113 & 78,6 \\
\hline 30 ppm (G4) & 61,2 & 67 & 62,5 & 87,5 & 69,5 \\
\hline Rata-rata & $62,6^{\mathrm{b}}$ & $68,3^{\mathrm{b}}$ & $64,6^{\mathrm{b}}$ & $97,6^{\mathrm{a}}$ & 73,2 \\
\hline
\end{tabular}

Superskrip yang berbeda pada baris yang sama menunjukkan perbedaan nyata $(\mathrm{p}<0,05)$

pembuatan larutan giberelin pada tanggal 23 Januari 2018 di Laboratorium Biologi FMIPA UNNES. Pembuatan larutan giberelin $10 \mathrm{ppm}$ dilakukan dengan giberelin sebanyak 0,01 gram dilarutkan dengan menambahkan $1 \mathrm{ml}$ ethanol 96\% ke dalam gelas ukur $1000 \mathrm{ml}$, kemudian ditambahkan aquades sampai volume akhir $1000 \mathrm{ml}$. Pembuatan larutan giberelin $20 \mathrm{ppm}$ dilakukan dengan giberelin sebanyak 0,02 gram dilarutkan dengan menambahkan $1 \mathrm{ml}$ ethanol 96\% ke dalam gelas ukur $1000 \mathrm{ml}$, kemudian ditambahkan aquades sampai volume akhir 1000 $\mathrm{ml}$. Pembuatan larutan giberelin $30 \mathrm{ppm}$ dilakukan dengan giberelin sebanyak 0,03 gram dilarutkan dengan menambahkan $1 \mathrm{ml}$ ethanol $96 \%$ ke dalam gelas ukur $1000 \mathrm{ml}$, kemudian ditambahkan aquades sampai volume akhir $1000 \mathrm{ml}$.

Penanaman bibit krisan dilakukan di Desa watt $/ \mathrm{m}^{2}$ diletakkan setinggi $1 \mathrm{~m}$ di atas pucuk tanaman untuk mendorong pembungaan. Penyinaran dilakukan mulai saat tanam sampai dengan periode menjelang fase generatif krisan yaitu delapan minggu setelah pemindahan ke lahan percobaan. Pemberian cahaya tambahan pada krisan dilakukan sesuai dengan perlakuan dimulai dari pukul 18.00 WIB. Tanaman diberi perlakuan zat pengatur tumbuh dengan cara menyemprotkan giberalin pada arah akar dan tunas, setiap 2 kali dalam seminggu selama 4 minggu saat tanaman krisan diperkirakan sudah akan tumbuh bunganya pada umur 1-4 minggu setelah tanam. Konsentrasi giberalin dilarutkan pada 1 liter aquades dibagi untuk 48 tanaman per bedengan yang dibagikan selama 4 minggu dengan dosis 2,6 cc per tanaman setiap penyemprotan. 
Tabel 2. Jumlah Daun Hasil Bunga Krisan pada Konsentrasi ZPT Giberalin dan Lama Penyinaran

\begin{tabular}{|c|c|c|c|c|c|}
\hline \multirow{2}{*}{$\begin{array}{c}\text { Konsentrasi } \\
\text { Giberalin (ppm) }\end{array}$} & \multicolumn{4}{|c|}{ Lama Penyinaran (Jam) } & \multirow[t]{2}{*}{ Rata-rata } \\
\hline & 1 jam $(\mathrm{R} 1)$ & 2 jam (R2) & 3 jam (R3) & 4 jam (R4) & \\
\hline & \multicolumn{5}{|c|}{ 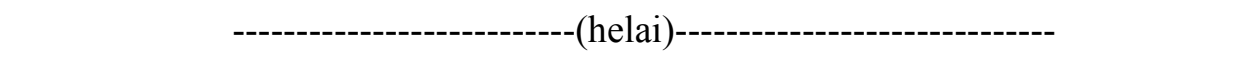 } \\
\hline 0 ppm (G1) & 52 & 57 & 52 & 82 & 60,7 \\
\hline $10 \mathrm{ppm}(\mathrm{G} 2)$ & 52 & 58 & 54 & 83 & 61,7 \\
\hline $20 \mathrm{ppm}(\mathrm{G} 3)$ & 52 & 60 & 55 & 96 & 65,7 \\
\hline 30 ppm (G4) & 51 & 57 & 51 & 76 & 58,7 \\
\hline Rata-rata & $51,7^{\mathrm{b}}$ & $58^{\mathrm{b}}$ & $53^{\mathrm{b}}$ & $84,2^{\mathrm{a}}$ & 61,7 \\
\hline
\end{tabular}

Superskrip yang berbeda pada baris yang sama menunjukkan perbedaan nyata $(\mathrm{p}<0,05)$

Selanjutnya melakukan pengamatan dan pengukuran yang dilakukan seminggu sekali, pengamatan dilakukan pada masing - masing perlakuan, setiap ulangan terdiri dari 48 sampel dengan 1 tanaman tiap lubang tanam untuk selanjutnya menganalisis data sesuai pengamatan. Penyiraman dilakukan dengan cara mengabutkan air hingga media dalam pot cukup basah. Pemberian perlakuan lama penyinaran dilakukan selama 35 hari yang terdiri dari 4 taraf yaitu 1 jam, 2 jam, 3 jam, dan 4 jam. Sedangkan pada perlakuan ZPT giberalin dilakukan selama 4 minggu dimulai dari 7 hari setelah tanam yang terdiri dari 4 taraf yaitu $0 \mathrm{ppm}, 10 \mathrm{ppm}, 20 \mathrm{ppm}$, dan $30 \mathrm{ppm}$.

\section{Rancangan Percobaan dan Analisis Data}

Rancangan yang digunakan dalam penelitian adalah Percobaan Faktorial 4x4 Rancangan Acak Lengkap (RAL). Faktor pertama yaitu perlakuan ZPT giberalin sebanyak 4 taraf berupa G1 : GA 0 ppm, G2 : GA 10 ppm, G3 : GA 20 ppm, G4 : GA $30 \mathrm{ppm}$. Faktor kedua yaitu lama penyinaran dengan 4 taraf berupa R1 : lama penyinaran 1 jam, $\mathrm{R} 2$ : lama penyinaran $2 \mathrm{jam}, \mathrm{R} 3$ : lama penyinaran 3 jam, dan R4 : lama penyinaran 4 jam. Percobaan terdiri dari 16 perlakuan dan masing-masing perlakuan diulang sebanyak tiga kali, sehingga terdapat 48 unit percobaan. Analisis ragam terhadap hasil pengamatan dilakukan dengan uji $\mathrm{F}$ dan uji lanjut Duncan MultipleRange Test (DMRT) pada taraf $5 \%$ untuk melihat perbedaan antar perlakuan

\section{HASIL DAN PEMBAHASAN}

\section{Tinggi Tanaman Krisan}

Hasil analisis ragam menunjukkan bahwa perlakuan lama penyinaran memberikan pengaruh nyata $(p<0,05)$ terhadap parameter tinggi tanaman krisan. Tidak terdapat pengaruh nyata pemberian konsentrasi giberalin terhadap parameter tinggi tanaman. Tidak terdapat pengaruh interaksi antara perlakuan konsentrasi ZPT giberalin dan lama penyinaran terhadap parameter tinggi tanaman krisan. Hasil DMRT perlakuan konsentrasi ZPT giberalin dan lama penyinaran dapat dilihat pada Tabel 1.

Hasil DMRT menunjukkan bahwa diantara lama penyinaran 1 jam, 2 jam, dan 3 jam tidak berbeda nyata pada tinggi tanaman, tetapi pada perlakuan lama penyinaran 1 jam, 2 jam, 3 jam menjadi 4 jam nyata $(\mathrm{P}<0,05)$ meningkatkan tinggi tanaman. Hasil penelitian menunjukkan bahwa perlakuan lama penyinaran 4 jam (R4) memiliki tinggi tanaman paling tinggi yaitu 97,6 $\mathrm{cm}$ sedangkan lama penyinaran 1 jam (R1) memiliki tinggi tanaman paling rendah yaitu 62,2 $\mathrm{cm}$. Hal tersebut menunjukkan tanaman krisan membutuhkan cahaya tambahan yang lebih lama untuk perpanjangan masa vegetatif, semakin panjang masa vegetatif maka semakin lama masa generatif tanaman yang terjadi sehingga proses pembungaan terjadi lebih lama dan tangkai 
Tabel 3. Diameter Bunga Hasil Bunga Krisan pada Konsentrasi ZPT Giberalin dan Lama Penyinaran

\begin{tabular}{|c|c|c|c|c|c|}
\hline \multirow{2}{*}{$\begin{array}{c}\text { Konsentrasi } \\
\text { Giberalin (ppm) }\end{array}$} & \multicolumn{4}{|c|}{ Lama Penyinaran (Jam) } & \multirow[t]{2}{*}{ Rata-rata } \\
\hline & 1 jam $(\mathrm{R} 1)$ & 2 jam (R2) & 3 jam (R3) & 4 jam (R4) & \\
\hline & \multicolumn{5}{|c|}{ 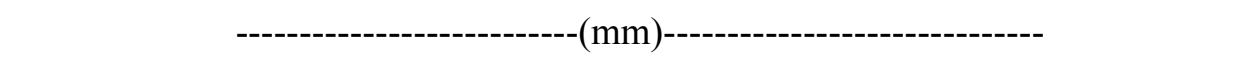 } \\
\hline 0 ppm (G1) & $8,2^{\mathrm{a}}$ & $7^{\mathrm{g}}$ & $6,1^{\mathrm{h}}$ & $7,8^{\mathrm{c}}$ & 7,2 \\
\hline $10 \mathrm{ppm}(\mathrm{G} 2)$ & $8,4^{\mathrm{a}}$ & $7,2^{\mathrm{f}}$ & $7,4^{\mathrm{e}}$ & $8,1^{\mathrm{b}}$ & 7,7 \\
\hline $20 \mathrm{ppm}(\mathrm{G} 3)$ & $8,5^{\mathrm{a}}$ & $7,8^{\mathrm{c}}$ & $7^{\mathrm{g}}$ & $7,7^{\mathrm{c}}$ & 7,7 \\
\hline 30 ppm (G4) & $8,6^{\mathrm{a}}$ & $6,3^{\mathrm{h}}$ & $7,5^{\mathrm{d}}$ & $7,7^{\mathrm{c}}$ & 7,5 \\
\hline Rata-rata & 8,4 & 7 & 7 & 7,8 & 7,5 \\
\hline
\end{tabular}

Superskrip yang berbeda pada matrik interaksi menunjukkan perbedaan nyata $(\mathrm{p}<0,05)$

tanaman yang dihasilkan lebih panjang. Semakin lama penambahan cahaya yang diberikan kepada tanaman krisan maka semakin panjang tangkai tanaman krisan. Perpanjangan masa vegetatif menurut Apriyanti (2012) dapat dilakukan dengan pemberian pencahayaan buatan dari lampu listrik yang dilakukan setelah matahari terbenam. Penambahan lama penyinaran membuat masa vegetatif lebih lama yang berpengaruh terhadap panjang tangkai bunga krisan. Pembudidayaan bunga krisan menurut Farid (2014) di daerah tropis dibutuhkan pengaturan hari panjang dengan penambahan cahaya lampu untuk memperpanjang masa vegetatifnya sehingga tangkai bunga lebih panjang.

\section{Jumlah Daun Tanaman Krisan}

Hasil analisis ragam menunjukkan bahwa perlakuan lama penyinaran memberikan pengaruh nyata $(p<0,05)$ terhadap parameter jumlah daun tanaman krisan. Tidak terdapat pengaruh nyata pemberian konsentrasi giberalin terhadap parameter jumlah daun tanaman krisan. Tidak terdapat pengaruh interaksi antara perlakuan konsentrasi ZPT giberalin dan lama penyinaran terhadap parameter jumlah daun tanaman krisan. Hasil DMRT perlakuan konsentrasi ZPT giberalin dan lama penyinaran dapat dilihat pada Tabel 2.

Hasil DMRT menunjukkan bahwa diantara lama penyinaran 1 jam, 2 jam, dan 3 jam tidak

Tabel 4. Diameter Batang Hasil Bunga Krisan pada Konsentrasi ZPT Giberalin dan Lama Penyinaran

\begin{tabular}{|c|c|c|c|c|c|}
\hline \multirow{2}{*}{$\begin{array}{c}\text { Konsentrasi } \\
\text { Giberalin (ppm) }\end{array}$} & \multicolumn{4}{|c|}{ Lama Penyinaran (Jam) } & \multirow[t]{2}{*}{ Rata-rata } \\
\hline & 1 jam $(R 1)$ & 2 jam $(R 2)$ & 3 jam (R3) & 4 jam (R4) & \\
\hline & \multicolumn{5}{|c|}{-----------------------------(mm)------------------------------- } \\
\hline 0 ppm (G1) & $0,40^{\mathrm{c}}$ & $0,37^{\mathrm{f}}$ & $0,49^{\mathrm{a}}$ & $0,43^{\mathrm{c}}$ & 0,42 \\
\hline $10 \mathrm{ppm}(\mathrm{G} 2)$ & $0,38^{\mathrm{d}}$ & $0,39^{\mathrm{d}}$ & $0,44^{\mathrm{b}}$ & $0,38^{\mathrm{d}}$ & 0,39 \\
\hline 20 ppm (G3) & $0,37^{\mathrm{f}}$ & $0,46^{\mathrm{b}}$ & $0,41^{\mathrm{c}}$ & $0,34^{\mathrm{g}}$ & 0,39 \\
\hline 30 ppm (G4) & $0,33^{\mathrm{h}}$ & $0,43^{\mathrm{c}}$ & $0,44^{\mathrm{b}}$ & $0,52^{\mathrm{a}}$ & 0,43 \\
\hline Rata-rata & 0,37 & 0,41 & 0,44 & 0,41 & 0,40 \\
\hline
\end{tabular}

Superskrip yang berbeda pada matrik interaksi menunjukkan perbedaan nyata $(\mathrm{p}<0,05)$ 
berbeda nyata pada pembentukan jumlah daun tanaman krisan, tetapi pada perlakuan lama penyinaran 1 jam, 2 jam, 3 jam menjadi 4 jam nyata $(\mathrm{P}<0,05)$ meningkatkan jumlah daun. Hasil penelitian menunjukkan bahwa perlakuan lama penyinaran 4 jam (R4) memiliki jumlah daun paling banyak yaitu 84 helai sedangkan lama penyinaran 1 jam (R1) memiliki jumlah daun paling sedikit yaitu 51 helai. Hal ini menunjukkan faktor panjang pendeknya hari mempengaruhi pertumbuhan organ daun. Tanaman krisan merupakan salah satu tanaman hari pendek yang memerlukan manipulasi lama penyinaran untuk perpanjangan masa vegetatif tanaman, perpanjangan masa vegetatif tanaman berpengaruh terhadap pertumbuhan tangkai tanaman. Manipulasi pencahayaan pada tanaman krisan menurut Ermawati (2011) akan menghasilkan tanaman krisan yang berumur panjang pada masa vegetatif sehingga jumlah daun lebih banyak dan tangkai bunga yang lebih panjang dibandingkan dengan tanaman krisan tanpa perlakuan cahaya tambahan. Tanaman krisan menurut Ermawati (2011) akan tumbuh lebih baik jika mendapatkan cahaya tambahan polikromatis. Tanaman krisan yang memperoleh penambahan cahaya polikromatis memiliki jumlah daun yang lebih banyak yang digunakan sebagai tempat fotosintesis

\section{Diameter Bunga Tanaman Krisan}

Hasil analisis ragam menunjukkan bahwa perlakuan lama penyinaran memberikan pengaruh nyata $(p<0,05)$ terhadap parameter diameter bunga tanaman krisan. Tidak terdapat pengaruh nyata pemberian konsentrasi giberalin terhadap diameter bunga krisan. Terdapat pengaruh interaksi antara perlakuan konsentrasi ZPT giberalin dan lama penyinaran terhadap parameter diameter bunga. Hasil DMRT perlakuan konsentrasi ZPT giberalin dan lama penyinaran dapat dilihat pada Tabel 3.

Hasil DMRT menunjukkan pada pengaruh interaksi antara pemberian ZPT giberalin dan lama penyinaran, yaitu menunjukkan bahwa pengaruh lama penyinaran tidak sama pada tiap level ZPT giberalin terhadap diameter bunga tanaman krisan. Berdasarkan hasil penelitian bahwa perlakuan konsentrasi giberalin 30 ppm (G4) dan lama penyinaran 1 jam (R1) memiliki diameter bunga paling tinggi yaitu $8,6 \mathrm{~mm}$ sedangkan pada perlakuan konsentrasi giberalin 0 ppm (G1) dan lama penyinaran 3 jam (R3) memiliki diameter batang tanaman paling rendah yaitu $6,1 \mathrm{~mm}$. Pemberian cahaya tambahan pada tanaman krisan berpengaruh dalam perpanjangan masa vegetatif tanaman sehingga proses pembungaan dapat tertunda dan hasil bunga yang tumbuh memiliki diameter yang lebih luas dibanding pertumbuhan bunga krisan tanpa perlakuan penambahan cahaya. Sedangkan zat pengatur tumbuh giberalin berperan dalam proses pembungaan tanaman sehingga pengaplikasian pemberian giberalin dan lama penyinaran yang dilakukan sangat membantu dalam fase pembungaan tanaman krisan. Salah

Tabel 5. Jumlah Bunga Hasil Bunga Krisan pada Konsentrasi ZPT Giberalin dan Lama Penyinaran

\begin{tabular}{|c|c|c|c|c|c|}
\hline \multirow{2}{*}{$\begin{array}{c}\text { Konsentrasi } \\
\text { Giberalin (ppm) }\end{array}$} & \multicolumn{4}{|c|}{ Lama Penyinaran (Jam) } & \multirow[t]{2}{*}{ Rata-rata } \\
\hline & 1 jam $(R 1)$ & 2 jam $(\mathrm{R} 2)$ & 3 jam (R3) & 4 jam (R4) & \\
\hline & \multicolumn{5}{|c|}{ 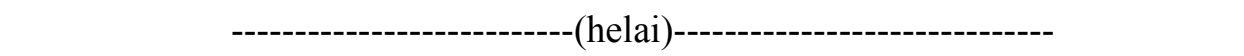 } \\
\hline 0 ppm (G1) & $21^{\mathrm{b}}$ & $19^{\mathrm{d}}$ & $21^{\mathrm{b}}$ & $20^{c}$ & 19 \\
\hline $10 \mathrm{ppm}(\mathrm{G} 2)$ & $22^{\mathrm{b}}$ & $19^{\mathrm{d}}$ & $20^{\mathrm{c}}$ & $20^{\mathrm{c}}$ & 20 \\
\hline 20 ppm (G3) & $16^{\mathrm{f}}$ & $26^{\mathrm{a}}$ & $17^{\mathrm{e}}$ & $19^{\mathrm{d}}$ & 19 \\
\hline 30 ppm (G4) & $15^{\mathrm{f}}$ & $17^{\mathrm{e}}$ & $19^{\mathrm{d}}$ & $19^{\mathrm{d}}$ & 17 \\
\hline Rata-rata & 18 & 20 & 19 & 19 & 18 \\
\hline
\end{tabular}

Superskrip yang berbeda pada matrik interaksi menunjukkan perbedaan nyata $(\mathrm{p}<0,05)$ 
satu cara menurut Soekarwati (2009) untuk mendapatkan tanaman krisan berbunga lebar adalah dengan pengaturan pencahayaan tambahan pada fase vegetatif dalam penundaan masa generatif pembentukan bunga. Tanaman krisan menurut Widyawan (2014) membutuhkan pencahayaan tambahan selama 3-6 minggu untuk pertumbuhan vegetatif sehingga proses pembungaan lebih lambat dan bunga yang dihasilkan memiliki diameter bunga lebih lebar.

\section{Diameter Batang}

Hasil analisis ragam menunjukkan bahwa perlakuan konsentrasi ZPT giberalin dan lama penyinaran memberikan pengaruh nyata $(p<0,05)$ terhadap parameter diameter batang tanaman krisan. Terdapat pengaruh interaksi antara perlakuan konsentrasi ZPT giberalin dan lama penyinaran terhadap parameter diameter batang. Hasil DMRT perlakuan konsentrasi ZPT giberalin dan lama penyinaran dapat dilihat pada Tabel 4.

Hasil DMRT menunjukkan pada pengaruh interaksi antara perlakuan konsentrasi ZPT giberalin dan lama penyinaran, yaitu menunjukkan bahwa pengaruh lama penyinaran tidak sama pada tiap level ZPT giberalin terhadap diameter batang krisan. Hasil tertinggi diameter batang dari perlakuan pemberian konsentrasi giberalin dan lama penyinaran terdapat pada perlakuan konsentrasi giberalin 30 ppm (G4) dan lama penyinaran 4 jam (R4) yaitu $0,52 \mathrm{~mm}$ sedangkan pada perlakuan konsentrasi giberalin 30 ppm (G4) dan lama penyinaran 1 jam (R1) memiliki diameter batang tanaman paling rendah yaitu 0,33 $\mathrm{mm}$. Zat pengatur tumbuh giberalin mempunyai peran dalam perluasan ruas organ tanaman sedangkan lama penyinaran membantu dalam perpanjangan dan pembelahan sel batang tanaman. Semakin tinggi konsentrasi giberalin dan lama penyinaran yang diberikan maka semakin luas diameter batang tanaman krisan. Lama penambahan cahaya menurut Indiraningsih (2011) dapat meningkatkan pertumbuhan tinggi tanaman, lingkar batang, berat basah, berat kering, serta memperpanjang masa vegetatif bunga krisan. Zat pengatur tumbuh giberalin menurut Asra dan Ubaidillah (2012) merupakan senyawa organik bukan nutrisi yang berperan dalam proses fisiologis tanaman. Zat pengatur tumbuh tersebut berperan dalam pembelahan sel batang, pertumbuhan dan perpanjangan batang, serta fase pembungaan. Peran giberalin menurut Sari dkk (2014a) dalam pemanjangan sel tanaman menyebabkan bertambahnya ruas tanaman dan diameter tanaman.

\section{Jumlah Bunga}

Hasil analisis ragam menunjukkan bahwa perlakuan konsentrasi ZPT giberalin memberikan pengaruh nyata $(\mathrm{p}<0,05)$ terhadap parameter jumlah bunga tanaman krisan. Tidak terdapat pengaruh beda nyata perlakuan lama penyinaran terhadap parameter jumlah bunga krisan. Terdapat pengaruh interaksi antara perlakuan konsentrasi

Tabel 6. Umur Berbunga Hasil Bunga Krisan pada Konsentrasi ZPT Giberalin dan Lama Penyinaran

\begin{tabular}{|c|c|c|c|c|c|}
\hline \multirow{2}{*}{$\begin{array}{c}\text { Konsentrasi } \\
\text { Giberalin (ppm) }\end{array}$} & \multicolumn{4}{|c|}{ Lama Penyinaran (Jam) } & \multirow[t]{2}{*}{ Rata-rata } \\
\hline & 1 jam (R1) & 2 jam (R2) & 3 jam (R3) & 4 jam (R4) & \\
\hline & \multicolumn{5}{|c|}{--------------------------(hari)---------------------------- } \\
\hline 0 ppm (G1) & 49 & 47 & 51 & 60 & 51 \\
\hline 10 ppm (G2) & 46 & 51 & 56 & 60 & 53 \\
\hline 20 ppm (G3) & 52 & 42 & 60 & 63 & 54 \\
\hline 30 ppm (G4) & 51 & 54 & 53 & 63 & 55 \\
\hline Rata-rata & $49^{\mathrm{b}}$ & $48^{c}$ & $55^{\mathrm{b}}$ & $61^{\mathrm{a}}$ & 53 \\
\hline
\end{tabular}

Superskrip yang berbeda pada baris yang sama menunjukkan perbedaan nyata $(\mathrm{p}<0,05)$ 
ZPT giberalin dan lama penyinaran terhadap parameter diameter batang. Hasil DMRT perlakuan konsentrasi ZPT giberalin dan lama penyinaran dapat dilihat pada Tabel 5 .

Hasil DMRT menunjukkan pada pengaruh interaksi antara perlakuan konsentrasi ZPT giberalin dan lama penyinaran, yaitu menunjukkan bahwa pengaruh lama penyinaran tidak sama pada tiap level ZPT giberalin terhadap jumlah bunga sebagai hormon tumbuh menurut Abidin (2012) selain berpengaruh terhadap sifat genetik, fotosintesis, pemanjangan batang juga berpengaruh terhadap pembungaan yatu digunakan untuk merangsang inisiasi pembungaan.

Krisan menurut Lingga (2011) merupakan tanaman hari pendek yang membutuhkan penyinaran cahaya lebih dari 12 jam untuk

Tabel 7. Luas Daun Hasil Bunga Krisan pada Konsentrasi ZPT Giberalin dan Lama Penyinaran

\begin{tabular}{cccccc}
\hline \hline \multirow{2}{*}{$\begin{array}{c}\text { Konsentrasi } \\
\text { Giberalin (ppm) }\end{array}$} & \multicolumn{4}{c}{ Lama Penyinaran (Jam) } & Rata-rata \\
\cline { 2 - 4 } & 1 jam (R1) & 2 jam (R2) & 3 jam (R3) & 4 jam (R4) & \\
\hline & & $-------------------\left(\mathrm{cm}^{2}\right)$---------------------- & \\
0 ppm (G1) & $27,5^{\mathrm{k}}$ & $20,7^{1}$ & $53,8^{\mathrm{e}}$ & $61 \mathrm{~b}, 4^{\mathrm{c}}$ & 40,8 \\
$10 \mathrm{ppm}(\mathrm{G} 2)$ & $28,3^{\mathrm{j}}$ & $40,7^{\mathrm{h}}$ & $46,8^{\mathrm{f}}$ & $65,9^{\mathrm{b}}$ & 45,4 \\
$20 \mathrm{ppm}(\mathrm{G} 3)$ & $36,5^{\mathrm{i}}$ & $58,7^{\mathrm{d}}$ & $43,7^{\mathrm{g}}$ & $59^{\mathrm{d}}$ & 49,4 \\
$30 \mathrm{ppm}(\mathrm{G} 4)$ & $29,3^{\mathrm{j}}$ & $62,2^{\mathrm{c}}$ & $46,2^{\mathrm{f}}$ & $67,6^{\mathrm{a}}$ & 51,3 \\
\hline Rata-rata & 30,4 & 45,5 & 47,6 & 63,4 & 46,6 \\
\hline
\end{tabular}

Superskrip yang berbeda pada matrik interaksi menunjukkan perbedaan nyata $(\mathrm{p}<0,05)$

krisan. Hasil penelitian menunjukkan bahwa perlakuan konsentrasi giberalin dan lama penyinaran terdapat pada perlakuan pemberian konsentrasi 20 ppm (G3) dan lama penyinaran 2 jam (R2) memiliki jumlah bunga paling tinggi yaitu 26 helai sedangkan pada perlakuan konsentrasi giberalin 30 ppm (G4) dan lama penyinaran 1 jam (R1) memiliki jumlah bunga paling rendah yaitu 15 helai.

Pemberian dosis giberalin yang berbeda menyebabkan laju pembungaan yang berbeda disetiap tanaman. Sedangkan lama penyinaran membantu dalam perpanjangan masa vegetatif sehingga proses pembungaan pada masa generatif dapat terjadi lebih lama dan bunga yang dihasilkan lebih banyak dengan diameter bunga yang luas. Ada beberapa zat pengatur tumbuh menurut Henny (2011) salah satunya adalah giberalin untuk mempengaruhi pertumbuhan, perkembangan maupun pergerakan taksis tanaman yang juga diketahui dapat meningkatkan keseragaman dan jumlah pembungaan tanaman krisan. Giberalin memperpanjang masa vegetatif sehingga pembentukan bunga lebih lama dan tanaman krisan yang dihasilkan membentuk tangkai yang panjang. Untuk mendapatkan tanaman krisan berbunga lebar menurut Widyawan (2014) adalah dengan pengaturan pencahayaan tambahan pada fase vegetatif dalam penundaan masa generatif pembentukan bunga. Tanaman krisan membutuhkan pencahayaan tambahan selama 3-6 minggu untuk pertumbuhan vegetatif sehingga proses pembungaan lebih lambat dan bunga yang dihasilkan lebih banyak dengan diameter bunga lebih luas.

\section{Umur Berbunga}

Hasil analisis ragam menunjukkan bahwa perlakuan lama penyinaran memberikan pengaruh nyata $(p<0,05)$ terhadap parameter umur berbunga tanaman krisan. Tidak terdapat pengaruh beda nyata pemberian ZPT giberalin terhadap parameter umur berbunga. Tidak terdapat pengaruh interaksi antara perlakuan konsentrasi 
ZPT giberalin dan lama penyinaran terhadap parameter umur berbunga tanaman krisan. Hasil DMRT perlakuan konsentrasi ZPT giberalin dan lama penyinaran dapat dilihat pada Tabel 6 .

Hasil DMRT menunjukkan pada lama penyinaran diantara lama penyinaran $1 \mathrm{jam}, 2 \mathrm{jam}$, dan 3 jam tidak berbeda nyata pada umur berbunga tanaman krisan, tetapi pada perlakuan lama penyinaran 1 jam, 2 jam, 3 jam menjadi 4 jam nyata $(0,05)$ meningkatkan umur berbunga. Hasil penelitian menunjukkan bahwa perlakuan lama penyinaran 4 jam (R4) memiliki umur berbunga paling panjang yaitu 61 hari sedangkan pada perlakuan lama penyinaran 2 jam (R2) memiliki umur berbunga paling pendek yaitu 48 hari. Perlakuan pemberian konsentrasi giberalin dan lama penyinaran berpengaruh pada umur berbunga tanaman krisan disebabkan pengaturan lama penyinaran membuat masa vegetatif berlangsung lebih panjang sehingga masa pembungaan yang terjadi lebih lama. Krisan merupakan tanaman hari pendek menurut Lingga (2011) sangat membutuhkan penyinaran cahaya lebih dari 12 jam untuk memperpanjang masa vegetatif sehingga pembentukan bunga lebih lama dan umur berbunga tanaman krisan menjadi lebih panjang. Secara alamiah tanaman krisan menurut Farid (2014) akan mengalami pertumbuhan vegetatif pada hari panjang tetapi akan mengalami perkembangan generatif pada hari pendek. Oleh karena itu, untuk membudidayakan tanaman krisan di daerah tropis dibutuhkan pengaturan hari panjang dengan penambahan cahaya lampu untuk memperpanjang masa vegetatifnya sehingga umur berbunga lebih panjang dan jumlah tangkai bunga lebih panjang.

\section{Luas Daun}

Hasil analisis ragam menunjukkan bahwa perlakuan konsentrasi giberalin dan lama penyinaran memberikan pengaruh nyata $(\mathrm{p}<0,05)$ terhadap parameter luas daun tanaman krisan. Terdapat pengaruh interaksi antara perlakuan konsentrasi ZPT giberalin dan lama penyinaran terhadap parameter luas daun tanaman krisan. Hasil DMRT perlakuan konsentrasi ZPT giberalin dan lama penyinaran dapat dilihat pada Tabel 7 .

Hasil DMRT menunjukkan pada pengaruh interaksi antara konsentrasi ZPT giberalin dan lama penyinaran, yaitu menunjukkan bahwa pengaruh lama penyinaran tidak sama pada tiap level ZPT giberalin terhadap parameter luas daun tanaman krisan. Berdasarkan hasil penelitian diperoleh hasil bahwa perlakuan konsentrasi 30 ppm (G4) dan lama penyinaran 4 jam (R4) memiliki luas daun paling banyak yaitu $67,6 \mathrm{~cm}$ sedangkan pada perlakuan konsentrasi ZPT giberalin 0 ppm (G1) dan lama penyinaran 2 jam (R2) memiliki luas daun paling rendah yaitu 20,7 $\mathrm{cm}$. Semakin tinggi konsentrasi giberalin dan lama penyinaran yang diberikan ke tanaman maka semakin luas diameter daun yang terbentuk. Lama penyinaran menurut Marjenah (2011) memberikan efek yang nyata terhadap luas daun, luas daun merupakan faktor utama dalam penentu kecepatan pertumbuhan dimana daun-daun yang mempunyai luas daun lebih besar mempunyai pertumbuhan tanaman yang lebih besar pula. Perbedaan respon tumbuhan terhadap lama penyinaran menurut Kurniyawan (2013) berpengaruh terhadap jumlah daun dan luas daun. Ketebalan dan luas daun dipengaruhi oleh intensitas cahaya yang diterima untuk meningkatkan proporsi daun dan luas daun yang lebih lebar. Respon pemberian giberalin terhadap pertumbuhan tanaman menurut Annisah (2009) berpengaruh terhadap peningkatan jumlah daun, luas daun, dan panjang akar. Zat pengatur tumbuh giberalin merupakan hormon tumbuh yang berpengaruh terhadap proses fotosintesis dimana semakin luas permukaan daun maka semakin cepat laju fotosintesis yang terjadi pada tanaman.

\section{KESIMPULAN}

Berdasarkan penelitian yang telah dilaksanakan diperoleh hasil bahwa pengaruh lama penyinaran tidak sama pada tiap level giberalin terhadap diameter bunga tanaman krisan. Kombinasi perlakuan konsentrasi ZPT giberalin $30 \mathrm{ppm} / \operatorname{tanaman}$ dan lama penyinaran 1 jam mampu menghasilkan diameter bunga tertinggi. Kombinasi perlakuan konsentrasi ZPT giberalin $30 \mathrm{ppm} /$ tanaman dan lama penyinaran 4 jam mampu menghasilkan luas daun tertinggi.

Saran yang dapat disampaikan untuk penelitian selanjutnya masih diperlukan penelitian lebih lanjut dengan dosis ZPT giberalin di antara 0-30 ppm/tanaman dan lama penyinaran di antara 2-3 jam untuk mengetahui efektifitas konsentrasi 
ZPT giberalin dan lama penyinaran terhadap pertumbuhan dan hasil bunga tanaman krisan.

\section{DAFTAR PUSTAKA}

Abidin. 2012. Peran Cahaya Tambahan pada Pertumbuhan Krisan. J. Horti 14 (2) : 204-311.

Ahmad. 2012. Krisan. J. Horti 72 (6) : 931-939.

Annisah. 2009. Pengaruh Induksi Giberalin. Penebar Swadaya, Jakarta.

Apriyanti. 2012. Pengaruh Cahaya Terhadap Budidaya Tanaman Krisan. Aneka Ilmu, Jakarta.

Asra, R. dan Ubaidillah. 2012. Pengaruh konsentrasi giberelin $\left(\mathrm{GA}_{3}\right)$ terhadap nilai nutrisi Calopogonium caeruleum. J. IlmuIlmu Peternakan 15(2) : 81-85.

2010. Luas Panen, Produksi, dan Produktivitas Krisan. BPS, Jakarta.

Bambang. 2006. Budidaya Krisan. Balai Pengkajian Teknologi Pemasaran Yogyakarta, Yogyakarta.

Barratt. M., Davies. J. Davies. 1997. Perubahan perkembangan respon pertumbuhan yang didorong oleh gibberellin pada segmen batang genotipe kacang hijau tumbuh. Peraturan Pertumbuhan Tanaman 21: 127134.

Budiarto. 2012. Budidaya Krisan Bunga Potong. Perlitbang Hortikultura, Jakarta.

Cao, L.Y., Yuan, S.J., Zhou, H.P., Zhan, X.D., Wu, W.M., Gao, J.X. dan Cheng, S.H. 2005. Pengaruh Berbagai Hormon pada Panjang Mesokotil pada Tanaman Padi. Acta Agronom 31: 1098-1100.

Chen, L., Higashitani, A., Suge, H., Takeda, K. dan Takahashi, H. 2003. Pertumbuhan spiral dan sifat dinding sel dari rongsokan pertama gibberell pada bibit kultivar gandum yang toleran terhadap kondisi menabur dalam. . Fisiologi Tanaman 118: 147-155.

Demeulemeester, M.A.C, Rademacher, W., Mierop, A. dan Proft, M.P. 1995. Pengaruh inhibitor biosintesis gibberellin pada elongasi batan don inisiasi bunga pada eksplan akar cl vitro dalam kondisi gelap dar 1. Regulasi Pertumbuhan Tanaman 17: 47-52.

De-Sheng Tsai, Arteca. N. 1985. Pengaruh aplikasi akar asam giberelat pada fotosintesis dan pertumbuhan pada tanaman $\mathrm{C} 3$ dan $\mathrm{C} 4$. Penelitian fotosintesis 6: 147-157.

Dewi, R., H. Sutrisno , dan Nazirwan. 2013. Pemulihan deteriorasi benih kedelai (glycine max 1.) dengan aplikasi giberelin. J. penelitian pertanian terapan 13(2) : 116122.

Edy. 2012. Pengaruh Cahaya Tambahan Pada Krisan. J. Teknologi 3 (2) : 120 - 130.

Ermawati. 2014. Pengaruh warna Cahaya Tumbuhan Terhadap Pertumbuhan dan Pembungaan Tiga Varietas Tanaman Krisan Potong Teknologi. J. Horti 3 (6) : 45-50.

Farid. 2011. Faktor-Faktor yang Mempengaruhi Pertumbuhan dan Perkembangan Tanaman. Kanisius, Yogyakarta.

Ferliati. 2013. Transgenik Tanaman Krisan. J. Bioteknologi 21 : 715-766.

Harjadi. 2013. Respon Tanaman Terhadap Penambahan Cahaya. J. Teknologi 3 (2) : $125-130$.

Henny. 2011. Hormon Giberelin dalam Induksi Bunga. Penerbit Rajawali, Jakarta.

Harry. 1994. Bunga Krisan. Nusa Indah, Yogyakarta. 
Hasim. 1995. Krisan. Penebar Swadaya, Jakarta.

Henny. 2011. Hormon Giberelin dalam Induksi Bunga. Penerbit Rajawali, Jakarta.

Indrianingsih, C. 2012, Pengaruh Perbedaan Lama Penambahan Cahaya Terhadap Pertumbuhan Vegetatif Tanaman Krisan, Jurusan Biologi Universitas Diponegoro, Semarang.

Khatak. 2013. Efek Pemberian Cahaya Tambahan dan Suhu pada pertumbuhan Krisan. J. Horti $435: 81-9$.

Kumar. 2008. Dasar-Dasar Pengetahuan Tentang Zat Pengatur Tumbuh. Angkasa, Bandung.

Kurniyawan. 2013. Meranti Merah di Berbagai Daerah. Diptrocarpa 7 (1). BPPPK, Samarinda.

Kusumo. 2014. Zat Pengatur Tumbuh Tanaman. Yaja Guva, Jakarta.

Lakitan. 2011. Dasar Dasar Fisiologi Tumbuhan. Raja Grafindo Persada, Jakarta.

Laksmanan. 2012. Zat Pengatur Tumbuh Tanaman. Bumi Aksara, Jakarta.

Libra. 2014. Pengaruh Umur Bibit dan Konsentrasi GA3 Terhadap Pembungaan Tanaman Krisan Standar (Chrysanthemum moriolium). Agronomika 9 (2) : 217-218.

Libra. 2014. Pengaruh Umur Bibit dan Konsentrasi GA3 Terhadap Pembungaan Tanaman Krisan Standar (Chrysanthemum moriolium). Agronomika, 9 (2) : 218-219.

Lilik. 2014. Respon Dua Kultivar Tanaman Krisan (Chrysanthemum morifolium) Pada Berbagai Lama Penambahan Cahaya Tambahan. J. Prosuksi Tanaman. 9 (1) : 1016

Lingga. 2011. Pengaruh cahaya terhadap tumbuhan, Institut pertanian Bogor, Bogor.
Marjenah. 2011. Pengaruh Perbedaan Naungan di Persemaian Terhadap Pertumbuhan dan Respon Morfologi Dua Jenis Semai Meranti. J. Ilmiah Kehutanan "Rimba Kalimantan" 7 (2), Samarinda.

Marwoto, B., L. Sanjaya dan K. Yuniarto. 2014. Hibridisasi Krisan dan Karakterisasi tanaman. J. Horti 14 (2) : 304-311.

Mulyatna. 2011. Krisan. Kanisius, Yogyakarta.

Nasihin. 2008). Teknik Perlakuan Periode Hari Panjang dan Pemberian GA3 Terhadap Produksi Bunga Potong Krisan. j. Buletin Teknik Pertanian. 13 (2) : 55-58.

Nishijima, T., Katsura, N., Koshioka, M., Yamazaki, H. dan Mander, L.N. 1997. Efek uniconazole dan GA3 pada elongasi batang yang diinduksi dingin dan flek Raphanus sativus L. Regul Pertumbuhan Tanaman 21: 207-214.

Onrizal. 2009. Bahan Ajar Silvika, Pertumbuhan Pohon Kaitannya dengan Tanah, Air, dan Iklim. Fakultas Pertanian Universitas Sumatra Utara, Sumatera Utara.

Reza. 1995. Budidaya Krisan. Kanisius, Yogyakarta.

Rukmana. 1997. Krisan (Seri Bunga Potong). Kanisius, Yogyakarta.

Sari, H.P., C. Hanum, dan Charloq. 2014a. Daya kecambah dan pertumbuhan Mucuna bracteata melalui pematahan dormansi dan pemberian zat pengatur tumbuh Giberelin $\left(\mathrm{GA}_{3}\right)$ J. Online Agroekoteknologi 2 (2) : 630-644.

Sarwono. 2012. Bunga Potong Komersial. Jurnal Agrotropika 12 (1) : 56-61.

Setyowati. 2012. Analisis Pertumbuhan Krisan. Balai Pengkajian Teknologi Pertanian Yogyakarta. Yogyakarta. 
Setyowati. 2012. Budidaya Tanaman Krisan. Balai Pengkajian Teknologi Pertanian Yogyakarta. Yogyakarta.

Soekarwati. 2009. Manajemen Agribisnis Bunga Potong. UI-Press, Jakarta.

Sutisna. 2010. Teknik Mempercepat Pembungaan Krisan (Chrysanthemum morifolium) dengan Pemberian GA3 dan Aplikasi Panjang Hari. J. Buletin eknik Pertanian. 15 (15)-19-23.

Tanaka, K., Nakamura, Y., Asami, T., Yoshida, S., Matsuo, T. dan Okamoto, S. 2003. sebagai auxin dalam pemanjangan hypocotyl yang tumbuh ringan. J. Regul Pertumbuhan Tanaman 22: 259-271.

Purwanto. 2009. Peranan Pengatur Tumbuh Tanaman. Kanisius, Yogyakarta.

Yamori .W., Hikosaka .K., and Way .D.A. 2013. Respon Suhu Fotosintesis pada Tanaman C3, C4, dan CAM. Resum Fotosintesis 10 (10):159- 168
Yang, T., Davies, P.J. dan Reid, J.B. 1996. Pembedahan genetik terhadap peran relatif auksin dan gibberellin dalam regulasi pemanjangan batang pada kacang polong yang tumbuh dengan baik. Tanaman physiol 110: 129-1034.

Yuwono. 2013. Krisan Seri Bunga Potong. Kanisius, Yogyakarta.

Watanabe, H., Hase, S. dan Saigusa M. 2007. Pengaruh penerapan gabungan Ethephon dan Gibberellin terhadap pertumbuhan bibit padi (Oryza sativa L.). Tanaman Prod. Sci 10: 468-472.

Widyastuti. 2014. Pengaruh Umur Bibit dan Konsentrasi GA3 Terhadap Pembungaan Tanaman Krisan (Chrysanthemum morifolium). J. Agronomika. 9 (2) : 217220.

Widyawan. 2014. Bunga Potong. Penebar Swadaya, Jakarta. 